\title{
Technical and economic analysis of a plant scale green house dryer for red onion bulb
}

\author{
Ana Nurhasanah ${ }^{1 *}$, Suparlan ${ }^{*}$, Suherman $S^{2}$ and Saleh Mokhtar ${ }^{3}$ \\ ${ }^{1}$ Center for Agricultural Engineering Research and Development, Indonesia \\ ${ }^{2}$ Department of Chemical Engineering, University of Diponegoro, Indonesia \\ ${ }^{3}$ Institute for Agricultural Technology, Central Kalimantan, Indonesia
}

\begin{abstract}
A green house dryer for red onion bulb with capacity $1000 \mathrm{~kg} / \mathrm{batch}$ was designed and tested. Dry wood was used as primary energy source of furnace for heating drying air, in which the drying room is also heated by solar energy. The ambient temperature and humidity of air are $28.9^{\circ} \mathrm{C}$ and $70.4 \%$, respectively. The velocity and temperature of drying air are $5.1 \mathrm{~m} / \mathrm{s}$ and $54.2^{\circ} \mathrm{C}$, respectively. The result show $1000 \mathrm{~kg}$ of red onion bulb with initial moisture content (wb) 0.87 for leaf and 0.86 for bulb can be dried become 0.14 and 0.82 in 35 hours. The temperature profile and moisture content of bulb in dryer room are almost homogeneous. After 1 month storage, yield and bulb damage are $77.2 \%$ and $1.68 \%$, respectively, is higher comparing by solar dryer in which yield is $72 \%$. Economic analysis as $\mathrm{B} / \mathrm{C}$ ratio give 4.6 .
\end{abstract}

\section{Introduction}

In Indonesia, the onion is one of the horticultural crops are cultivated people, especially in Brebes, Central Java Province. Average production of onion in Java ranged from 7.42 to 9.94 tonnes/hectare (MoA, 2004). The increase in production has not fully benefit farmers. Onion is one of perishable agricultural commodities. Post harvest damage that often occurs in onions is the growth of shoots, softening the tubers, root growth and decay and the emergence of a dark-colored mass due to fungus. This damage resulted in decreasing the shelf life and quality of onion. To resolve this issue needed proper postharvest handling. The critical point of failure in post-harvest handling, especially when the onion harvest occurs in the rainy season, is in the drying stage of withering and drying of leaves or tubers. The failure of the process of withering the leaves can cause spoilage bacteria infection, whereas the failure of drying the bulbs can cause low shelf life, rapid tuber rot, sprout and root out. Yield losses due to this damage could reach $20-40 \%$ (BB Pascapanen MOA) [1-5].

Usually the farmers conduct drying of onion bulb by sun drying in which takes between 7-9 days. This drying technique is highly depending on weather conditions. In sunny weather, the drying proces could take place, neverthelessin cloudy or even rainy weather drying completely unable to accomplish, as a result shallot into a fast decay. To solve this problem, in 2007 Indonesian Instution Postharvest Technology introduces drying-storage system (instore Drying), which in this system space conditions can be set according to the optimum conditions for drying-storage onions. In this study, the drying-storage buildings (instore Drying) with a capacity of 5-10 tons was developed. The dimension of building is $6 \mathrm{~m}$ of long, $3 \mathrm{~m}$ of wide, and $6 \mathrm{~m}$ of high. The roof of the building is made by transparent fiber glass equipped with air aeration (ball window) fiber glass wall of the building. The drying rack-storage in the form of a hanging rack is made of bamboo stalks. The instore drying drying can dry bulb onion within 3 days, in which is faster than the sun drying in 9 days. In addition, in store drying also do not cause significant damage is only between $0.24-0.72 \%$ is much lower when compared to sun drying wherethe level of damage could reach $1.68 \%$. The technology in store drying was implemented in 2008 in Brebes, Central Java [6,7].

Therefore, this paper will show the technical and economical analysis of A Plant Scale of Green House Dryer for onion bulb. The dryer is developed from instore drying models. The implementation of dryer is conducted in in Palangkaraya, Province of Central Kalimantan, in 2014 .

\section{Methodology}

The research was carried out by Center for Agricultural Technology (BPTP) Central Kalimantan in MarchtoDecember, 2014. Figures 1 and 2 shows design of dryer. A green house dryer was built by Polycarbonate, galvanish pipe 2 -inch steel plate, angle steel $40 \times 40$, iron box $40 \times 40$, plate Eser $3 \mathrm{~mm}$, aluminum wire mesh, fan with $50 \mathrm{~cm}$ of diameter, fireproof bricks and others. The fuel for operating dryer is diesel oil and firewood. Testing equipment is thermohygrometer, moisture tester, anemometer, pyranometer, digital scales, a thermocouple, a data recorder, rough scales, stop watch, measuring cups and others (Figure 3).

\section{Results and discussion}

\section{The dimension and component of dryer}

The farmers conduct sun drying after harvest by binding onions

Correspondence to: Ana Nurhasanah, Center for Agricultural Engineering Research and Development, Serpong Tromol Pos 2, Serpong, Tangerang, Banten, 15310, Indonesia, Tel: 622170936787; E-mail: ana_nur2001@yahoo.com

Key words: red onion bulb, green house, tray dryer, solar

Received: December 14, 2016; Accepted: January 02, 2017; Published: January 06, 2017 

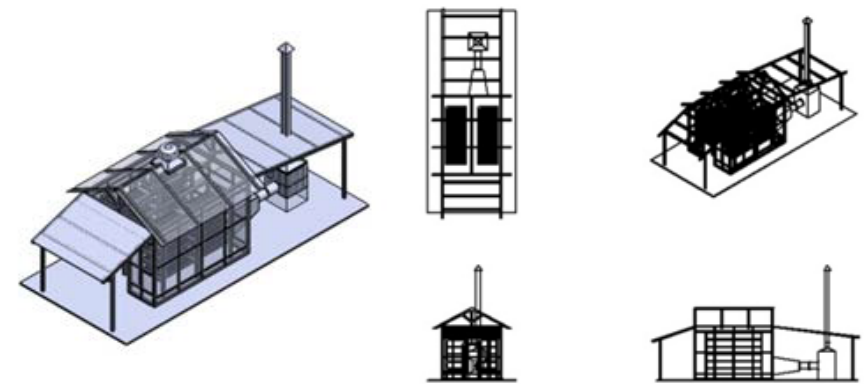

Figure 1. Design of a plant scale green-house dryer for onion bulb.

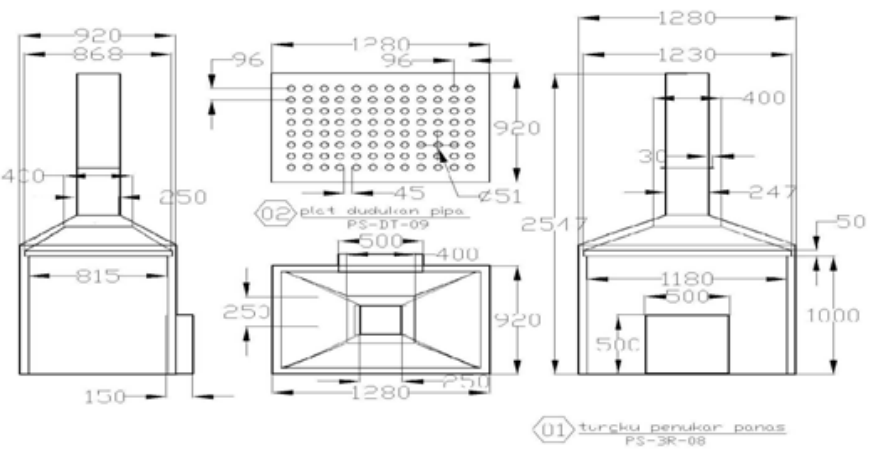

Figure 2. Detail design of furnace.
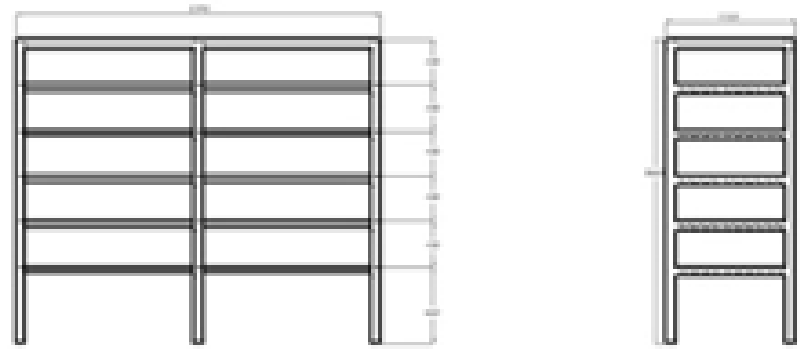

frestuien

notvien

Figure 3. Design tray of dryer.

grove of about $1 \mathrm{~kg}$ per clump. The sun drying could be conducted in approximately three days when the weather is nice. If the weather is cloudy, then approximately four days for drying process. For using as onion seeds, the onions are hung on the rack for a month or two months. For using as consumption, the onions can be directly sold after drying in about a week. Prices of onion in the farmer's consumption of around Rp. 18,000-19,000, while for the seeds around Rp. 21,00022,000 , per kilogram. The sales process is made directly by middle men who come to onion farmers. When the rainy season, onion becomes rotten, and this is an obstacle for farmers due to the price of onion will be decreases dramatically, and then the level of losses is quite high. To deal with the problem of drying in the rainy season, the onion dryer with a capacity of approximately $500-1000 \mathrm{~kg}$ have to be build [8-10].

A greenhouse onion dryer with heat sources derived from biomass stove with fire wood was developed. The dried material is storaged on the rack. The rack is performed from a pile of bamboo, in which the final water content in onion bulb will achieve in good condition. Onion shallot, red onion leaves and stems is more evenly. The dryer has five main components, namely:

1. Dryer room: The walls and roof of dryer room is made with transparent Polycarbonate plastic material so that the sun's heat can enter and heat the house dryer. Dryer room is designed in accordance with the size of the rack used added space to facilitate in flow of material to be dried. Dimensions of dryeris $3 \times 4$ meters made of polycarbonate with wood frame beams $40 \mathrm{~mm}$. Dryer roof is made form polycarbonate plastic for more robust and easier to set up. Table 1 shows the dimension of dryer (Figure 4).

2. Tray: Designed shelves stacked with distance between shelves 40 $\mathrm{cm}$ to facilitate the insert and expend of onion. The racks are arranged vertically in one section because of the length of onion leaves about 40 $\mathrm{cm}$ and 6 rack consists of two parts of the right and left of the direction of spending blower. Each section comprising a rack 6 rows of shelves.

Table 1. Dimensions Dryers onion-type greenhouse.

\begin{tabular}{|l|l|l|l|}
\hline \multirow{2}{*}{ Description } & \multicolumn{3}{|l|}{ DimensionEngineering(mm) } \\
\cline { 2 - 3 } & Length & Width & Height \\
\hline Overallunit & 10380 & 3300 & 3900 \\
\hline Buildingdryer & 10380 & 3300 & 3800 \\
\hline FurnaceUnit(Heater) & 4830 & 1150 & 3800 \\
\hline DryerRackUnit(tray) & 4400 & 95 & 2580 \\
\hline
\end{tabular}

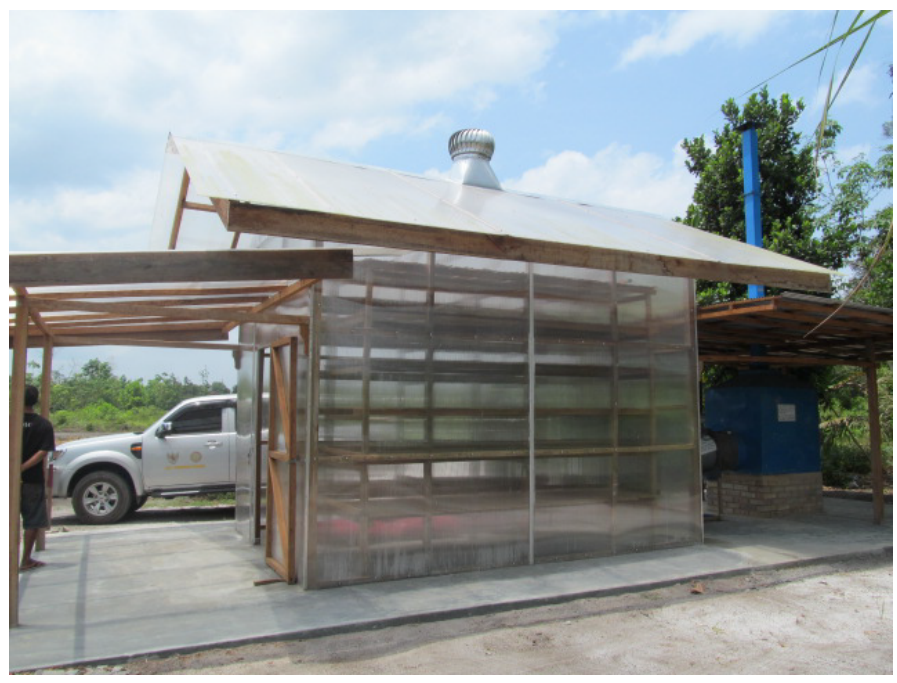

Figure 4. Building a green-house dryer.

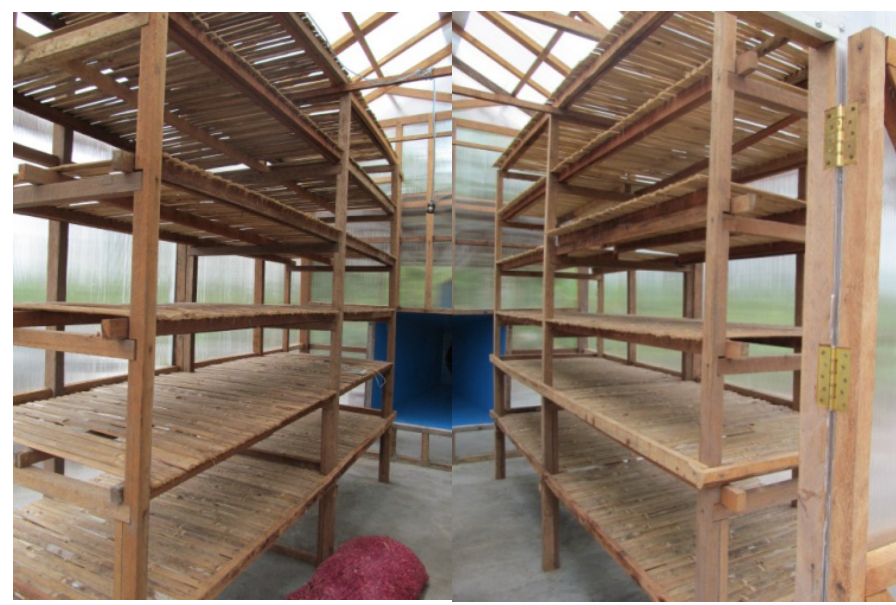

Figure 5. Structuring tray-dryer. 
Frame made of wood and bamboo balk that are not gathering for the circulation of hot air. Shelves are made with a size of $4 \times 1 \mathrm{~m}$ with a capacity of $90 \mathrm{~kg} / \mathrm{shelf}$. The dryer is designed with a total of 12 rack shelf for dryer capacity of approximately 1,000 kg (Figure 5) [11].

3. Furnacesand heat exchanger: Furnace used wood as biomass fuel. The heat generated from the combustion and transfer to air drying by heat exchanger. By using a heat exchanger, the air entering the drying chamber is not mixed with the combustion fumes; due to dust combustion products, could eventually alter the taste of dried onion. Heat exchanger is built by 48 pieces of galvanized pipe with a thickness of $2 \mathrm{~mm}$ by 2 -inch length of 1 meter. A smoke exhaust stack is made of steel plate thickness of $2 \mathrm{~mm}$ diameter 6 inches with a height of $4 \mathrm{~m}$ (Figure 6).

4. Blower: Blower is used to circulate drying air. Hot air that has passed through the heat exchanger is blown into the drying room. After contact with bulb onion, the drying air straight out through the vortex that is placed at the top of the drying room. The axial blowertype is used with diameter of 24 inches $(50 \mathrm{~cm})$. This blower can blow the air with a turbulent flow so that the entire space can be exposed to the drying air.

5. Turbin: Turbines with $400 \mathrm{~mm}$ diameter will intake drying air and mounted on the roof of the drying room. This turbine serves to assist the circulation of hot air that carries water vapor out of the drying room. Hot air that comes out of the blower will pass through a pile of wet red onion and bring the water vapor out through the turbines.

\section{Performance testing of dryer}

Table 2 shows the data of ambient temperature and air humidity. Table 3 shows performancedata and operating conditions of dryer.

The type of onion is Brebes variety. The harvested condition is $84.5 \%$ for moisture content and $1.8 \mathrm{~cm}$ for bulb diameter. The comparison of average weight between bulb onion with leaves and stems of approximately $75 \%$ and $25 \%$. The binding process is done for withering number of products of $500 \mathrm{~kg}$. Products that have been tied up then placed on the shelves of the dryer, in which there is a space between these products. The drying process is performed, with the controlled air temperature and air velocity.The temperature and velocity distribution of drying air are measured at some point drying rack. Other parameters are also measured namely onion bulbs temperature,exhaust air temperature, and exhaust gases exit the furnace chimney. Based on the literature review and the initial purpose of this study, that the initial drying process (=withering) are performed for around 16 hours at a temperature of $46^{\circ} \mathrm{C}$ [12-15].

From the measurement results show;
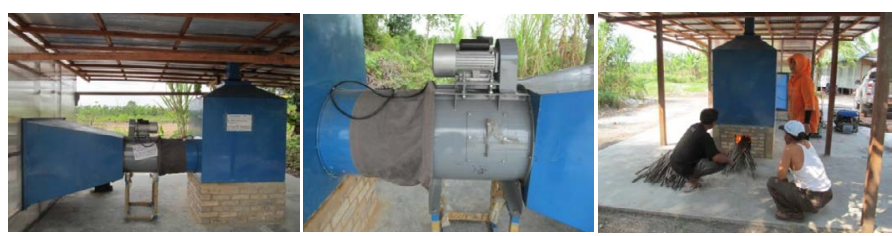

Figure 6. Furnace and heat exchanger.

Table 2. Data of ambient temperature and air humidity.

Ambient air temperature

\begin{tabular}{|l|l|}
\hline - average & $32.8^{\circ} \mathrm{C}$ \\
\hline - $m a x i m u m$ & $37.7^{\circ} \mathrm{C}$ \\
\hline - minimum & $28.9^{\circ} \mathrm{C}$ \\
\hline Ambient air humidity average & $70.40 \%$ \\
\hline
\end{tabular}

Table 3. Data performance and operating conditions of dryer.

\begin{tabular}{|l|c|}
\hline Drying capacity $(\mathrm{kg} / \mathrm{batch})$ & 1000 \\
\hline Velocity of drying air $(\mathrm{m} / \mathrm{s})$ & $3.1-8.1$ \\
\hline Drying air temperature average $\left({ }^{\circ} \mathrm{C}\right)$ & 58.1 \\
\hline Solid temperature average $\left({ }^{\circ} \mathrm{C}\right)$ & 54.2 \\
\hline Room temperature average $\left({ }^{\circ} \mathrm{C}\right)$ & 32.8 \\
\hline Motor fuel flow rate $(\mathrm{lt} / \mathrm{h})$ & 1 \\
\hline Indoor air humidity average $(\mathrm{lt} / \mathrm{h})$ & 70.4 \\
\hline Fire wood flow rate $(\mathrm{kg} / \mathrm{h})$ & 20 \\
\hline Solar flow rate $(\mathrm{lt} / \mathrm{h})$ & 1 \\
\hline Drying thermal efficiency $(\%)$ & 16.23 \\
\hline Drying efficiency $(\%)$ & 49.24 \\
\hline
\end{tabular}

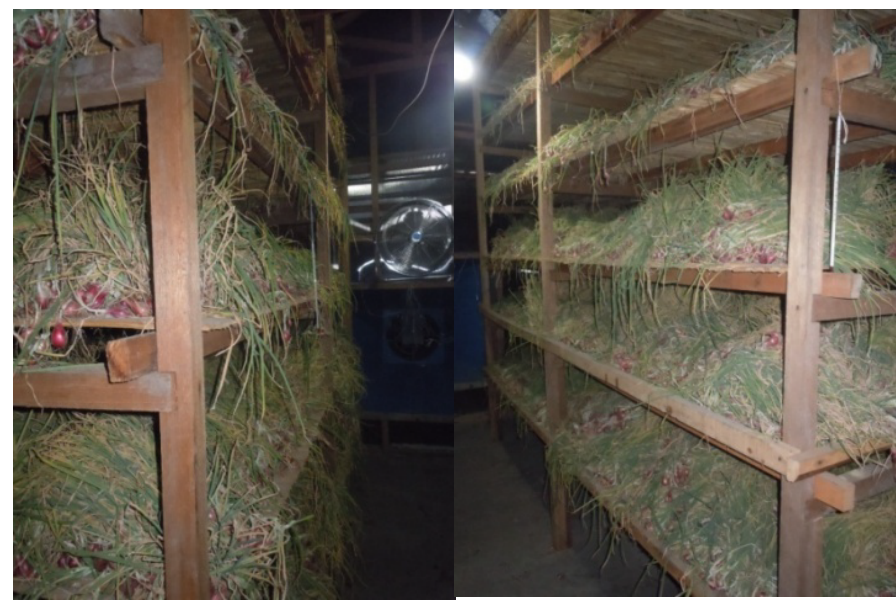

Figure 7. Withering process using the dryer for 17hours.

1. Distribution of drying air velocity: Drying air velocity distribution is uneven. Most of the drying air flowing is in the middle, which is the hall where path to put the product to the shelves dryer. In the middle section near the front of the fan, the air speed reaches $14.8 \mathrm{~km} / \mathrm{h}$. On the shelf above the left and right, the air velocity is $0.1 \mathrm{~km} / \mathrm{h}$. However, the drying air can reach up to the middle or the back of the hall with a velocity of $3.3 \mathrm{~km} / \mathrm{h}$.

2. Distribution of drying air temperature: The distribution of the drying air temperature is almost evenly. At the front, a good middle, right and left, nearly uniform temperature is about $44^{\circ} \mathrm{C}$. At the center, a good middle, right and left, nearly uniform temperature is about $42^{\circ} \mathrm{C}$. On the back, either center, right and left, the temperature is nearly uniform about $41^{\circ} \mathrm{C}$ (Figure 7).

3. Measurement of drying air relative humidity conditions: Measurement of drying air relative humidity conditions is only performed on two points on the front. From observation, the drying air temperature is almost constant, and with the passage of the drying process, the drying air relative humidity conditions continue to decline. At the beginning of process, drying air relative humidity is $43 \%$, one hour later decreased to $42 \%$, and 2 hours later to $41 \%$. While the temperature and ambient air relative humidity (outside the dryer) was $28.4^{\circ} \mathrm{C}$ and $70 \%$, respectively. Increasingly night air temperature and relative humidity decreased further, for example at $20: 00$ hours $27.2^{\circ} \mathrm{C}$ of temperature and $73 \%$ of relative humidity.

4. Distribution of the product drying rate: From visual observations drying rate product looks very slow and not uniform. This is occured due to the part in direct contact with the drying air is only the upper part of tray. At the end of drying, the leaf is dry, while the middle and 
lower leaf stalks still fresh. It can be concluded that the drying process is less successful, because the distribution of quality products that arenotuniform.

5.The exhaust gas temperature: The air temperature in the chimney flue gas is still very high between $95-100^{\circ} \mathrm{C}$. This could be a potential use of the exhaust gas as a preheater for the drying air (Figure 8).

\section{Technical analysis}

1. Effect of temperature and humidity: The performance of dryer was evaluated at various temperatures. The result is also compared with drying onions using sunlight (Figure 9). Results showed that the drying speed is proportional to the temperature rise. This is understandable because the higher the temperature, the air capability of carrying or even evaporate the water from the material will increase. With low humidity air, the water from material will move faster into the air. This study is also in line with previous studies, in which the rise in temperature will increase the rate of evaporation of water from the material into the air (Figure 9) [16,17].

2. Effect of air flow rate: At this drying, air velocity varies at a speed of 0.2 and $8.1 \mathrm{~m} / \mathrm{s}$. Results showed that the higher the air velocity, the higher the drying rate (Figure 10).

3. Evaluation of the quality of onion: The purpose of this drying is to decrease moisture content of onion below $15 \%$, where moisture content in onion bulb is $80-85 \%$. The water content in the outer layer is about $15 \%$ (same as the leaves). Tuber dry outer layer will protect the bulbs inside, so that the onions remain fresh and not rotten ormushroomedwhenstored.

Evaluation was conducted on dried onion product consists of a physical test includes the final moisture content, percentage of damage and loss percentage, and the percentage of tuber rot/damaged. The physical evaluation performed during two months of storage. After a month of storage, the percentage of yield is $77.2 \%$. The percentage of onion bulbs damage because since the beginning of unsorted around $1.68 \%$. These result is still entered in the Quality category I for

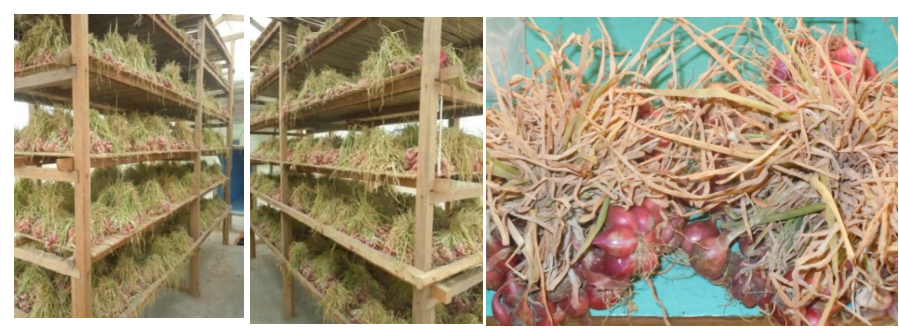

Figure 8. The drying process continued after withering (left), and red onion drying results (right) Comparison with sun dried after the process of with erring day before.

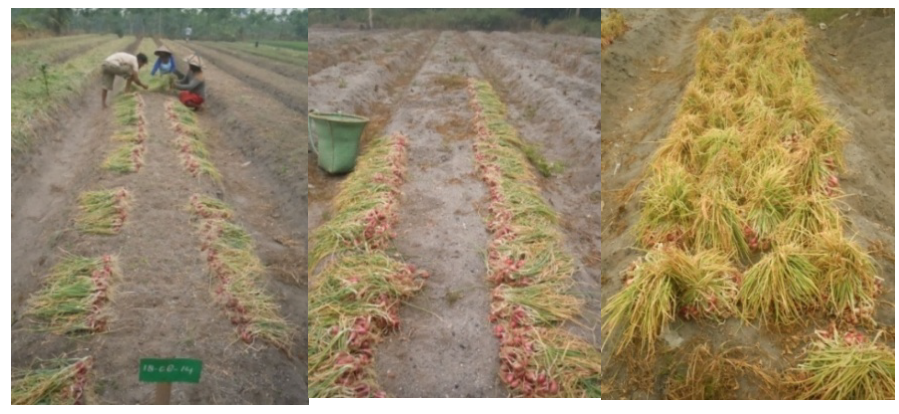

Figure 9. The process of witherring red onions after harvest with sunlight.

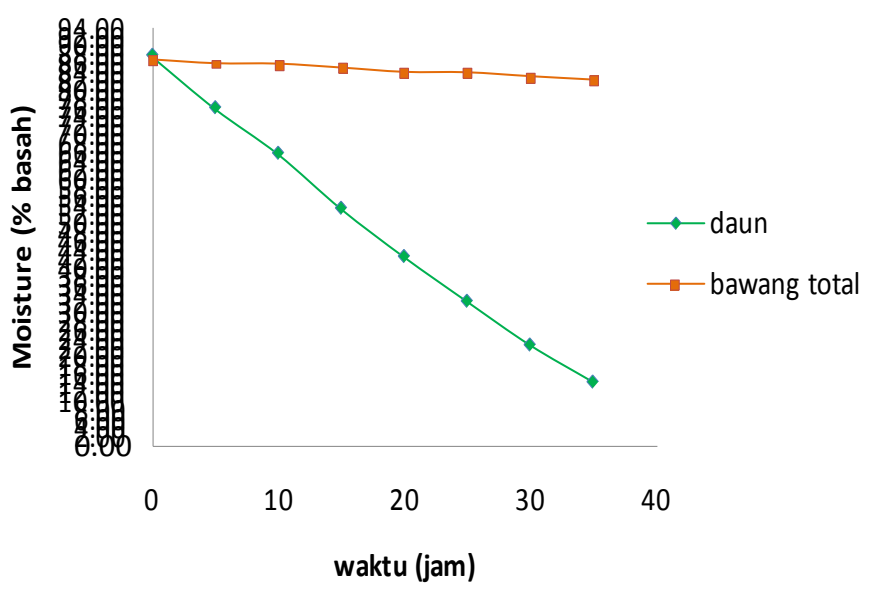

Figure 10. Profile of moisture content for leaf and onion bulb.

Indonesia National Standard (SNI) of red onion. Compared to drying use sunlight, the onion yield is $72 \%$.

\section{Economic analysis}

Economic analysis showed that operational costs of drying onion use green house dryer is Rp. 10.368/kg whereas using sunlight Rp. 9.200/ $\mathrm{kg}$. The dryer is operated when the season is cloud. The comparison shows the little difference rupiah per kg between green house dryer and sun drying. The advantage gained by using a dryer is work of farmers is becoming more effective because it does not require a land area, more hygienic, less labor, and more practical in storage. The biggest advantage is harvest during the rainy season. In this time, there is no sunlight so that the quality of the onion can be maintained, and prices remain high. From economic calculation,the $\mathrm{B} / \mathrm{C}$ ratio is 4.6. It means the dryer will get back after five years [18-20].

\section{Conclusions and suggestions}

The performance of a green housedryer hybrid solar-biomass has been tested and work well for drying red onion bulb in 34 hourswithdrying air temperaturesaverage $41-50^{\circ} \mathrm{C}$.

This dryer must be pursued more perfect functioning through modification blower drive system components. The addition of 6.5 HP diesel engine can be used drying onion continuously. The farmers income canincrease.

Drying machine are assessed fairly good prospects for development in Central Kalimantan. The farmers is enthusiastic to try to use the dryer. There is already a replica of dryer by other farmers.

\section{References}

1. Chavan BR, Yakupitiyage A, Kumar S (2008) Mathematical modeling of drying characteristics of indian mackerel (Rastrilliger kangurta) in solar-biomass hybrid cabinet dryer. Drying Technology 26: 1552-1562.

2. Chen HH, Huang, Tzou-Chi, Tsai, Chien-Hsiung, et al. (2009) Development and Performance Analysis of a New Solar Energy-Assisted Photocatalytic Dryer. Drying Technology 26: 503-507.

3. Downes K, Chope GA, Terr LA (2009) Effect of curing at different temperatures on biochemical composition of onion (Allium cepa L.) skin from three freshly cured and cold stored UK-grown onion cultivars. Postharvest Biol Technol 54: 80-86.

4. Downes K, Chope GA, Terry LA (2010) Postharvest application of ethylene and 1-methylcyclopropene either before or after curing affects onion (Allium cepa L.) bulb quality during long term cold storage. Postharvest Biol Technol 55: 36-44.

5. Gregorio MRP, García-Falcón MS, Simal-Gándara J (2011) Flavonoids changes in 
fresh-cut onions during storage in different packaging systems. Food Chem 124: 652-658.

6. Gregorio RMP, Mercedes SGF, Jesu's SG, Ana SR, Domingos PFA(2010) Identification and quantification of flavonoids in traditional cultivars of redand white onions at harvest. Journal of Food Composition and Analysis 23: 592-598

7. Hassanain AA (2010) Unglazed transpired solar dryers for medicinal plants. Drying Tech 28: 240-248.

8. Hole CC, Drew RLK, Gray D (2000) Humidity and mechanical properties of onion skins. Postharvest Biol Technol 19: 229-237

9. Hole CC (2001) Onion quality is only skin deep. Grower 22: 14-15.

10. Hole CC, Drew RLK, Gray D (2002) in characteristics and quality of onion cultivars given different nitrogen and irrigation treatments. J Hortic Sci Biotechnol 77: 191-199.

11. Hossain MA, Amer BMA, Gottschalk K (2008) Hybrid solar dryer for quality dried tomato. Drying Technology 26: 1591-1601.

12. Isenberg FM, Ang JK (1963) Northern grown onions: curing, storing and inhibiting sprouting. Cornell Extension Bulletin 1116, Cornell University, New York.

13. Janjai S, Lamlert N, Intawee P, Mahayothee B, Boonrod Y, et al. (2009) Solar drying of peeled longan using a side loading type solar tunnel dryer: experimental and simulated performance. Drying Technology 27: 595-605.

14. Leon MA, Kumar S (2008) Design and Performance Evaluation of a Solar-Assisted Biomass Drying System with Thermal Storage. Drying Technology 26: 936-947.

15. Mawa BW, Mullinix BG (2005) Moisture loss of sweet onions during curing Postharvest Biol Technol 35: 223-227

16. Miedema P (1994) Bulb dormancy in onion. I. The effects of temperature and cultivar on sprouting and rooting. Journal of Horticultural Science 69: 29-39.

17. Nonclercq A, Cédric Boey LS, Lonys L, Dave B, Haut B (2009) Construction of a solar drying unit suitable for conservation of food and enhancement of food security in West Africa. Food Sec 1: 197-205.

18. Phoungchandang S, Nongsang S, Sanchai P (2009) The development of ginger drying using tray drying, heat pump-dehumidified drying, and mixed-mode solar drying. Drying Technology 7: 1123-1131.

19. Rathore NS, Panwar NL (2010) Design and development of energy efficient solar tunnel dryer for industrial drying. Clean Techn Environ Policy, 2010.

20. Tsotsas dan Mujumdar (2011) Modern Drying Technology, Wiley.

Copyright: $@ 2017$ Nurhasanah A. This is an open-access article distributed under the terms of the Creative Commons Attribution License, which permits unrestricted use, distribution, and reproduction in any medium, provided the original author and source are credited. 